Jurnal Pemikiran \& Penelitian Psikologi

\title{
PSIKOLOGIA
}

p-ISSN: $185-0327$

e-ISSN: $2549-2136$

www.jurnal.usu.ac.id/psikologia

\section{PERSEPSI TERHADAP DUKUNGAN ORGANISASI SEBAGAI MEDIATOR PENGARUH EMPLOYEE EMPOWERMENT TERHADAP KOMITMEN ORGANISASI}

\author{
THE PERCEPTION OF ORGANIZATION SUPPORT AS A \\ MEDIATOR THE EFFECT OF EMPLOYEE EMPOWERMENT \\ TOWARD ORGANIZATIONAL COMMITMENT \\ Daniel Subangkit Purba, Emmy Mariatin, Siti Zahreni \\ Psikologia: Jurnal Pemikiran \& Penelitian Psikologi \\ Tahun 2017, Vol. 12, No. 3, hal.153-164
}

Artikel ini dapat diakses dan diunduh pada:

www.jurnal.usu.ac.id/psikologia

\section{Dipublikasikan oleh:}

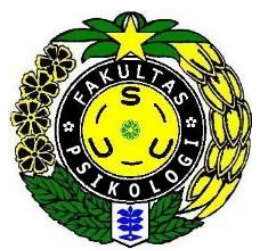

Fakultas Psikologi

Universitas Sumatera Utara

J1. Dr. Mansyur No. 7 Medan. Telp/fax: 061-8220122

Email: psikologia@usu.ac.id 



\title{
PERSEPSI TERHADAP DUKUNGAN ORGANISASI SEBAGAI MEDIATOR PENGARUH EMPLOYEE EMPOWERMENT TERHADAP KOMITMEN ORGANISASI
}

\author{
Daniel Subangkit Purba, Emmy Mariatin, Siti Zahreni \\ Universitas Sumatera Utara
}

\begin{abstract}
ABSTRAK
Penelitian ini bertujuan untuk mengetahui pengaruh empowerment terhadap persepsi dukungan organisasi, pengaruh persepsi dukungan organisasi terhadap komitmen organisasi, dan efek mediasi persepsi dukungan organisasi pada pengaruh antara empowerment dengan komitmen organisasi. Pengumpulan data penelitian dilakukan dengan menggunakan skala, yaitu skala komitmen organisasi, skala persepsi dukungan organisasi, dan skala empowerment. Penelitian ini dilakukan di kantor pusat PT. X dengan jumlah subjek penelitian sebanyak 161 orang. Hasil analisis regresi sederhana untuk hipotesis pertama menyimpulkan bahwa ada pengaruh signifikan empowerment terhadap persepsi dukungan organisasi sebesar $65,5 \%$. Sedangkan untuk hipotesis kedua didapatkan hasil ada pengaruh signifikan persepsi dukungan organisasi terhadap komitmen organisasi, yang besarnya adalah $46,8 \%$. Dari hasil uji hipotesis mediasi, disimpulkan bahwa persepsi dukungan organisasi memediasi pengaruh antara empowerment dan komitmen organisasi, di mana mediasi yang dihasilkan adalah mediasi sempurna.
\end{abstract}

Kunci : empowerment, persepsi dukungan organisasi, komitmen organisasi, mediasi sempurna, regresi.

\section{THE PERCEPTION OF ORGANIZATION SUPPORT AS A MEDIATOR THE EFFECT OF EMPLOYEE EMPOWERMENT TOWARD ORGANIZATIONAL COMMITMENT}

\begin{abstract}
S
This research was aimed to examine the effect of empowerment toward the perception of organization support, the effect perception of organization support toward organization commitment, and the effect of mediation perception of organization support on the effect of empowerment with organization commitment. The research data was collected by used scale, organizational commitment scale, organizational support perception scale, and empowerment scale. This research was conducted at PT. X with the number of research subjects as many as 161 people. The results of simple regression analysis for the first hypothesis concluded that there is a significant effect of empowerment toward perception of organization support at $65.5 \%$. As for the second hypothesis obtained results there is significant effect of perception of organization support toward organization commitment, which amount is $46.8 \%$. From the results of hypothesis mediation test, it is concluded that the perception of organization support mediated the effect between empowerment and organization commitment, which the mediation produced is perfect mediation.
\end{abstract}

Keyword: Empowerment, perception of organization support, organization commitment, perfect mediation, regretion.

*Korespondensi mengenai penelitian ini dapat dilayangkan kepada: Psikologia@usu.ac.id
Rekomendasi mensitasi:

Purba,D.S. Mariatin,E. \& Zahreni,S. (2017). Persepsi

Terhadap Dukungan Organisasi Sebagai Mediator Pengaruh Employee Empowerment Terhadap Komitmen Organisasi. Psikologia: Jurnal Pemikiran dan Penelitian Psikologi, 12(1), 153-164. 
Menurut Elnaga dan Imran (2014), manusia merupakan salah satu faktor paling penting dalam menciptakan kinerja perusahaan yang unggul, di mana keberhasilan atau kegagalan perusahaan sangat bergantung pada kinerja dari sumber daya manusia di dalam perusahaan. Manajer atau pimpinan harus seoptimal mungkin mengusahakan agar para individu dalam organisasi dapat lebih berkomitmen dan memberikan kontribusi dalam pencapaian tujuan perusahaan (Maskat, 1993). Mowday et al. (1982) menyatakan bahwa dengan mengerti bagaimana komitmen dapat terbentuk akan memberikan dampak yang signifikan terhadap proses kerja secara keseluruhan baik kepada karyawan, organisasi, dan masyarakat secara keseluruhan.

Banyak penelitian yang telah dilakukan untuk melihat faktor - faktor apa saja yang mempengaruhi tinggi rendahnya tingkat komitmen karyawan di dalam organisasi, salah satunya adalah persepsi karyawan terhadap dukungan yang diberikan perusahaan kepadanya, yang menurut beberapa ahli merupakan salah satu faktor yang esensial dalam membentuk komitmen karyawan dalam organisasi (Dursun 2015; Alkalin, 2006). Menurut Kraimer (2001), ada dua jenis bentuk dukungan organisasi yaitu dukungan intrinsik seperti gaji, tunjangan, dan bonus serta dukungan ekstrinsik seperti misalnya perhatian, pemberdayaan, pujian, penerimaan, keakraban, informasi, dan pengembangan diri.

Menurut Elnaga dan Imran (2014), empowerment merupakan salah satu metode manajemen sumber daya manusia yang dapat dijalankan untuk meningkatkan efisiensi dan efektifitas di dalam bekerja. Dengan melibatkan karyawan pada pengambilan keputusan strategis, akan membuat organisasi lebih fleksibel dan responsif dalam menghadapi perubahan, dan selanjutnya hal ini akan meningkatkan efektifitas dan efisiensi kerja baik secara individual maupun untuk organisasi secara keseluruhan (Meyerson, 2012).

Berdasarkan pemaparan di atas, peneliti tertarik untuk melakukan penelitian mengenai pengaruh empowerment terhadap komitmen organisasi dengan dimediasi oleh persepsi karyawan terhadap dukungan organisasi. Hal ini mengingat pemberdayaan karyawan, terutama dalam hal pengambilan keputusan secara mandiri dewasa ini menjadi relevan, mengingat tren yang umum pada saat ini adalah penerimaan karyawan dengan pengetahuan yang luas, desentralisasi dalam pengambilan keputusan, dan struktur perusahaan yang lebih organisasi (Baird \& Wang, 2010).

\section{KERANGKA TEORITIS}

\section{Komitmen Organisasi}

Menurut Mowday et al. (1982) komitmen karyawan pada organisasi merupakan keterikatan karyawan dengan organisasi yang dikarakteristikkan dengan adanya keyakinan yang kuat dan penerimaan terhadap tujuan dan nilai organisasi, kemauan untuk memberikan usaha yang lebih terhadap organisasi dan dorongan yang kuat untuk mempertahankan keanggotaan dalam organisasi. Mathis dan Jackson (2001) mendefenisikan bahwa komitmen organisasi sebagai tingkat kepercayaan dan peneriman pekerja terhadap tujuan organisasi dan mempunyai keinginan untuk tetap ada dalam organisasi tersebut yang pada akhirnya tergambar dalam statistik kehadiran dan masuk keluarnya pekerja dari organisas 
Menurut Kreitner dan Kinicki (2004), komitmen organisasi mencerminkan sejauh mana seorang individu mengidentifikasi dirinya dengan organisasi dan tujuannya. Hal tersebut merupakan sikap kerja yang penting karena orang yang berkomitmen diharapkan untuk menampilkan kemauan bekerja lebih keras untuk mencapai tujuan organisasi dan keinginan yang lebih besar untuk tetap dipekerjakan di dalam organisasi.

\section{Persepsi Terhadap Dukungan Organisasi}

Persepsi Dukungan Organisasi menurut Eisenberger et al. (2002) adalah keyakinan karyawan mengenai sejauh mana organisasi peduli terhadap kesejahteraan mereka dan menghargai kontribusi mereka. Keyakinan yang dimaksud adalah terdapatnya konsistensi dari para karyawan mengenai berbagai penilaian dari organisasi yang mungkin diberikan kepada mereka dan berbagai tindakan yang dapat dilakukan organisasi baik menguntungkan maupun merugikan bagi mereka.

Persepsi terhadap dukungan organisasi adalah keyakinan seseorang bahwa organisasi tempat dia bekerja menghargai kontribusinya dan peduli akan kesejahteraannya (Rhoades, Eisenberger, dan Armeli, 2001). Persepsi terhadap dukungan organisasi juga dinilai sebagai jaminan bahwa bantuan akan tersedia dari organisasi pada saat dibutuhkan untuk menjalankan pekerjaan seseorang secara efektif dan pada saat menghadapi situasi yang sangat menegangkan (Rhoades \& Eisenberger, 2002). Persepsi bahwa karyawan dihargai oleh organisasi menguatkan keyakinan karyawan bahwa organisasi akan memenuhi kewajibannya untuk mengenali sikap dan perilaku karyawan, serta selanjutnya memberi penghargaan yang mereka inginkan. Penghargaan ini bisa dalam bentuk informal seperti pujian dan mentoring maupun formal seperti promosi dan kenaikan gaji (Wayne et al., 1997).

\section{Empowerment}

Randolph (1995) menyatakan bahwa empowerment adalah proses transfer kekuasaan atau tanggung jawab dari atasan kepada bawahannya. Menurut Stewart (1998) empowerment berarti memberi kesempatan kepada karyawan untuk merencanakan, melaksanakan rencana, dan mengendalikan rencana pekerjaan yang menjadi tanggung jawabnya atau tanggung jawab kelompoknya. Sedangkan Hales dan Klidas (1998) mendefenisikan empowerment sebagai suatu proses berbagi pengetahuan, informasi, dan kekuasaan dari atasan kepada bawahan langsungnya. Shackelton (1995) mendefinisikan empowerment sebagai suatu sistem terukur tentang bagaimana memberikan tanggung jawab lebih atau kekuasaan untuk mengambil keputusan kepada bawahan di dalam organisasi. Pendapat berbeda menyatakan bahwa empowerment bukan hanya sekedar memberikan keleluasaan dalam bekerja, akan tetapi memberikan tugas - tugas atau tanggung jawab yang lebih tinggi dari pada yang dimiliki karyawan sebelumnya (Blanchard, Carlos, \& Randolph, 1995).

$\begin{array}{ccc}\text { Menurut } & \text { Shackelton } & (1995), \\ \text { pemberdayaan } & \text { berbeda } & \text { dengan } \\ \text { pendelegasian } & \text { tanggung } & \text { jawab. }\end{array}$
Menurutnya, pendelegasian adalah ketika atasan memberikan sebagian tugas tugasnya kepada bawahannya untuk alasan tertentu, misalkan ketika atasan ingin 
berlibur maka ia akan meminta bawahan untuk melaksanakan sebagian tugasnya. Sedangkan empowerment berarti memberikan tanggung jawab lebih, baik secara kuantitas atau pun kualitas kerja, tanpa mengubah struktur tugas yang diberikan.

\section{HIPOTESIS}

\section{Gambar 3. 1. Kerangka pemikiran}

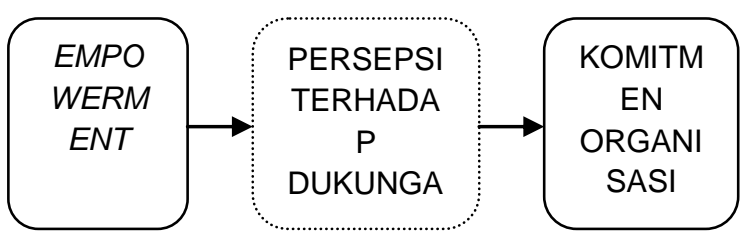
berikut :

Hipotesis penelitian adalah sebagai

a. Ada pengaruh signifikan empowerment terhadap persepsi dukungan organisasi, di mana semakin positif persepsi karyawan terhadap proses empowerment yang dilakukan semakin positif pula persepsi karyawan terhadap dukungan yang diberikan organisasi, dan sebaliknya.

b. Ada pengaruh signifikan persepsi terhadap dukungan organisasi dengan komitmen organisasi, di mana semakin positif persepsi karyawan terhadap dukungan yang diberikan oleh organisasi, akan semakin tinggi pula komitmen karyawan terhadap perusahaan.

c.

Persepsi terhadap dukungan organisasi bertindak sebagai mediator pengaruh antara empowerment dengan komitmen organisasi.

\section{METODE PENELITIAN}

Metode pengumpulan data yang digunakan pada penelitian ini adalah metode kuesioner. Penyusunan kuesioner dalam penelitian ini menggunakan skala likert yang digunakan untuk mengukur sikap, pendapat, dan persepsi seseorang atau sekelompok orang mengenai suatu objek (Sugiyono, 2011). Skala yang digunakan adalah skala persepsi terhadap dukungan organisasi. skala empowerment, dan skala komitmen organisasi.

\section{UJI ASUMSI PENELITIAN}

\section{Hasil Uji Normalitas}

Uji normalitas pada penelitian ini menggunakan analisis skewness-kurtosis dalam menentukan sebaran datanya normal atau tidak. Menurut Santoso (2000), kaidah uji adalah ketika rasio skewness dan kurtosis berada diantara -2 sampai +2 maka sebaran datanya adalah normal.

Tabel 1. Hasil Uji Normalitas

\begin{tabular}{ccc}
\hline VARIABEL & SKEWNESS & KURTOSIS \\
\hline Komitmen & $-0,640$ & 0,284 \\
POS & $-0,432$ & $-0,638$ \\
Empowerment & $-0,778$ & $-0,178$ \\
\hline
\end{tabular}

\section{Hasil Uji Linearitas}

Uji asumsi linearias pada penelitian ini akan menggunakan teknik test for linearity yang ada pada program spss for windows. Dari hasil pengolahan data yang dilakukan didapatkan hasil sebagai berikut:

Tabel 2. Hasil Uji Asumsi Linearitas

\begin{tabular}{lcc}
\hline \multicolumn{1}{c}{ VARIABEL } & F & P \\
\hline Empowerment - POS & 308,988 & 0,000 \\
Empowerment - & 87,765 & 0,000 \\
Komitmen Organisasi & & \\
POS - Komitmen & 161,026 & 0,000 \\
Organisasi & & \\
\hline
\end{tabular}

\section{Hasil Uji Autokorelasi}

Tabel 3. Hasil Uji Autokorelasi 


\begin{tabular}{lc}
\hline \multicolumn{1}{c}{ VARIABEL } & $\begin{array}{c}\text { Durbin - } \\
\text { Watson }\end{array}$ \\
\hline Empowerment - POS & 1,491 \\
Empowerment - Komitmen & 1,985 \\
Organisasi & \\
POS - Komitmen Organisasi & 2,101 \\
Empowerment + POS - & 2,103 \\
Komitmen Organisasi & \\
\hline
\end{tabular}

Dari hasil di atas, dapat dilihat bahwa untuk keempat hubungan antar variabel di dapatkan nilai Durbin - Watson yang lebih besar dari satu dan lebih kecil dari tiga. Sesuai dengan kaidah, maka dari hasil ini dapat disimpulkan bahwa keempat hubungan antara variabel tidak memiliki autokorelasi.

\section{Uji Multikolinearitas}

\section{Tabel 12. Hasil Uji Multikolinearitas}

\begin{tabular}{lcc}
\multicolumn{1}{c}{ VARIABEL } & TOLERANCE & VIF \\
\hline Empowerment + & & \\
POS - Komitmen & 0,343 & 2,914 \\
Organisasi & & \\
\hline
\end{tabular}

Dari tabel 12 dapat dilihat bahwa dari hasil analisis didapatkan nilai VIF $<10$ dan nilai tolerance $>0,1$. Dari hasil ini dapat disimpulkan bahwa tidak terjadi multikolinearitas antara variabel independen, yaitu empowerment dan persepsi terhadap dukungan organisasi.

\section{Uji Heteroskedastisitas}

Dari seluruh model regresi, didapatkan hasil bahwa tidak ada yang menunjukkan adanya gejala heteroskedastisitas. Hal ini disimpulkan dari pola yang ada pada grafik dari setiap model regresi keempatnya menunjukkan pola yang menyebar (no systematic pattern) bukan mengumpul.

Sesuai kaidah yang ada apabila pola grafik menyebar dan tidak mengumpul atau membentuk pola tertentu (misalnya garis) maka dikatakan tidak ada gejela heteroskedastisitas pada model regresi.

\section{UJI HIPOTESIS}

\section{Uji Hipotesis Pertama}

Hasil analisis regresi antara variabel empowerment dengan persepsi terhadap dukungan organisasi didapatkan hasil $\mathrm{R}=$ $0,810, F=304,292$, dengan signifikansi (p) $=0,000$. Dari nilai ini dapat disimpulkan bahwa ada hubungan antara empowerment dengan persepsi terhadap dukungan organisasi. Selain itu juga didapatkan nilai koefisien determinasi (adjusted $R$ square) sebesar 0,655 atau $65,5 \%$. Hal ini berarti variasi perubahan persepsi terhadap dukungan organisasi dapat dijelaskan oleh empowerment sebesar $65,5 \%$, sedangkan sisanya dapat dijelaskan oleh variabel lainnya selain empowerment.

Dari hasil analisis ini, dapat disimpulkan bahwa hipotesis pertama yang menyatakan ada pengaruh signifikan empowerment terhadap persepsi dukungan organisasi diterima.

\section{Uji Hipotesis Kedua}

Hasil analisis regresi antara variabel persepsi dukungan organisasi dengan komitmen organisasi didapatkan hasil $\mathrm{R}=$ $0,687, F=141,887$, dengan signifikansi (p) $=0,000$. Dari nilai ini dapat disimpulkan bahwa ada hubungan antara persepsi terhadap dukungan organisasi dengan komitmen organisasi. Selain itu juga didapatkan nilai koefisien determinasi (adjusted $R$ square) sebesar 0,468 atau $46,8 \%$. Hal ini berarti variasi perubahan komitmen organisasi dapat dijelaskan oleh persepsi karyawan terhadap dukungan organisasi sebesar 46,8\%, sedangkan sisanya yaitu $53,2 \%$ dapat dijelaskan oleh variabel lainnya.

Dari hasil analisis regresi di atas dapat disimpulkan bahwa hipotesis yang 
menyatakan ada pengaruh signifikan persepsi terhadap dukungan organisasi dan komitmen organisasi diterima.

\section{Uji Hipotesis Ketiga}

Uji efek mediasi pada penelitian ini akan menggunakan metode analisis regresi linear. Baron dan Kenny (1986) menjelaskan prosedur analisis variabel mediator secara sederhana melalui regresi. Tahap - tahap yang dilakukan untuk menguji efek mediasi dengan menggunakan regresi linear menurut Baron dan Kenny (1986) adalah sebagai berikut :

1. Melakukan regresi linear untuk Y dengan X sebagai prediktor (Selanjutnya disebut jalur c)

2. Melakukan regresi linear untuk $M$ dengan $X$ sebagai prediktor (selanjutnya disebut jalur a)

3. Melakukan regresi linear untuk $\mathrm{Y}$ dengan $\mathrm{M}$ sebagai prediktor (selanjutnya disebut jalur b)

4. Melakukan regresi linear untuk $\mathrm{Y}$ dengan $\mathrm{X}$ dan $\mathrm{M}$ sebagai prediktor (selanjutnya disebut jalur $\left.c^{\prime}\right)$

Hasil uji regresi dari masing - masing tahapan dapat dilihat pada gambar berikut ini :

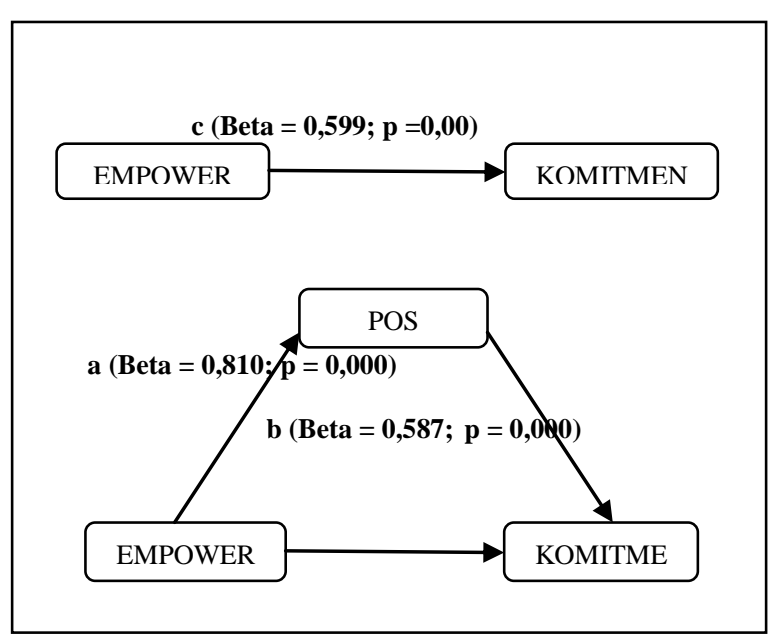

Dari gambar tersebut, apabila kita bandingkan pengaruh variabel empowerment terhadap komitmen organisasi secara langsung dan ketika mengendalikan variabel mediator maka dapat kita lihat adanya penurunan koefisien regresi yaitu dari 0,599 menjadi 0,124. Selain itu, terjadi juga perubahan taraf signifikansi, dari yang sebelumnya berpengaruh signifikan dengan $\mathrm{p}=0,000$ menjadi tidak berpengaruh dengan $\mathrm{p}=$ 0,210 .

Berdasarkan kaidah yang dikemukakan oleh Baron dan Kenny (1986) menyatakan bahwa sebuah variabel memediasi secara sempurna ketika ada perubahan pengaruh saat variabel tersebut diregresikan dengan mengendalikan variabel mediator (koefisien regresi c' tidak signifikan dan lebih kecil dari koefisien regresi c). Berdasarkan pendapat ini, dari hasil analisis disimpulkan bahwa variabel persepsi terhadap dukungan oganisasi bertindak sebagai mediator sempura dari pengaruh empowerment terhadap komitmen organisasi.

Oleh karena itu, hipotesis ketiga yang menyatakan bahwa persepsi dukungan organisasi bertindak sebagai mediator pengaruh antara empowerment terhadap komitmen organisasi diterima.

\section{PEMBAHASAN}

\section{Pembahasan Hipotesis Pertama}

Dari hasil analisis yang telah dilakukan dapat disimpulkan bahwa empowerment memiliki hubungan yang kuat dengan persepsi terhadap dukungan organisasi dengan pengaruh yang diberikan sebesar sebesar 65,5\%. Hal ini menunjukkan semakin efektif proses pemberdayaan yang dilakukan oleh perusahaan maka akan meningkatkan 
persepsi karyawan terhadap dukungan organisasinya.

Empowerment merupakan salah satu bentuk praktik sumber daya manusia di dalam perusahaan, di mana proses pemberdayaan karyawan mencakup pemberian tugas - tugas baru dengan tanggung jawab yang lebih besar terhadap karyawan atau memberikan keleluasaan dalam merencanakan dan melaksanakan pekerjaannya kepada karyawan (Blanchard, Carlos, \& Randolph, 1995; Stewart, 1998). Sebagai praktek - praktek sumber daya manusia maka proses pemberdayaan itu sendiri akan mempengaruhi secara signifikan bagaimana persepsi karyawan terhadap dukungan dari organisasi kepadanya (Allen, Shore, \& Griffith 2003). Apabila seluruh proses pemberdayaan karyawan dilakukan dengan baik, mulai dari pendelegasian tugas, proses pengerjaan, sampai kepada penghargaan yang diberikan, maka akan membuat karyawan merasa didukung dalam proses kerja.

Hasil penelitian ini sejalan dengan yang didapatkan oleh Salazar (2000) serta Mishra dan Speitzer (1998) yang menyimpulkan bahwa apabila karyawan diberdayakan secara tepat oleh perusahaan maka akan meningkatkan perasaan berarti dan kepercayaan diri karyawan yang selanjutnya akan membentuk persepsi yang positif dari karyawan terhadap dukungan yang diberikan organisasi dalam proses kerja. Sejalan dengan itu, menurut Parameswari dan Rahyuda (2014) serta Boudrias et al (2010) juga menyimpulkan di dalam penelitiannya bahwa seorang atasan yang memberdayakan karyawan dalam praktek - praktek manajerialnya akan membuat karyawan merasa perusahaan telah berlaku adil terhadapnya, sehingga pada akhirnya hal itu akan membuat semakin positifnya persepsi karyawan terhadap dukungan yang diberikan organisasi di dalam proses kerja.

\section{Pembahasan Hipotesis Kedua}

Dari hasil analisis yang telah dilakukan, dapat disimpulkan bahwa ada pengaruh persepsi terhadap dukungan organisasi dengan komitmen organasisasi. Di mana, semakin positif persepsi seorang karyawan terhadap dukungan yang diberikan perusahaan di dalam proses kerja maka akan semakin tinggi pula komitmen karyawan tersebut kepada perusahaannya, yang ditandai dengan pemahaman dan internalisasi terhadap identitas organisasi, kemauan untuk bekerja lebih keras dari yang diharapkan, serta kesetiaan kepada perusahaan.

Berdasarkan teori pertukaran sosial yang dikemukakan oleh Gouldner (1960), menyatakan bahwa karyawan merasa ada kewajiban untuk memberikan sesuatu kepada organisasi ketika mereka menganggap bahwa organisasi juga telah memberikan sesuatu kepada mereka. Ketika perusahaan telah menunjukkan dukungan yang baik dan menyeluruh di dalam proses kerja, maka akan meningkatkan persepsi positif karyawan terhadap dukungan dari organisasi. Semakin positif persepsi karyawan tersebut, berarti kepuasan kerjanya semakin meningkat. Ketika karyawan terlah melihat perusahaan memenuhi kewajiban - kewajibannya, maka di dalam diri karyawan akan muncul keinginan untuk membalas perlakukan tersebut. Karyawan akan semakin berkomitmen terhadap pekerjaaan dan perusahaan, di mana ia mau untuk bekerja keras demi kelangsungan hidup perusahaan serta loyal terhadap perusahaan. Demikian sebaliknya, ketika dukungan yang diberikan 
perusahaan belum maksimal maka justru akan meningkatkan persepsi negatif karyawan terhadap perusahaan. Hal ini juga akan menimbulkan keinginan untuk membalas dengan perlakukan - perlakuan yang tidak mendukung bahkan menghambat pekerjaannya, sehingga pada akhirnya akan menghambat kinerja perusahaan secara keseluruhan.

Gunduz (2014) juga menyebutkan bahwa salah satu prediktor dari komitmen organisasi adalah dukungan organisasional yang diberikan organisasi kepada karyawannya. Demikian juga menurut Loi, Hang-Yuey, dan Foley (2006) yang menyatakan bahwa komitmen organisasi merupakan salah satu konsekuensi penting dari persepsi positif terhadap dukungan yang diberikan oleh organisasi. Di mana karyawan dengan persepsi yang positif terhadap dukungan dari organisasi akan merasa berkewajiban untuk membalas dukungan ersebut dengan cara memberikan perilaku - perilaku yang positif di dalam bekerja untuk memenuhi tujuan yang diberikan organisasi kepada mereka.

\section{Pembahasan Hipotesis Ketiga}

Dari hasil uji hipotesis yang telah dilakukan, didapatkan hasil bahwa persepsi terhadap dukungan organisasi bertindak sebagai variabel mediator untuk hubungan antara empowerment dengan komitmen organisasi. Hal ini berarti, ketika di dalam perusahaan sudah dijalankan proses empowerment, belum tentu akan mempengaruhi komitmen karyawan pada organisasi, tetapi ditentukan bagaimana persepsi karyawan terhadap dukungandukungan yang diberikan oleh organisasi di dalam proses empowerment yang dilakukan.
Seperti telah dikemukakan di atas bahwa empowerment merupakan salah satu bentuk praktik - praktik sumber daya manusia di dalam perusahaan, di mana proses pemberdayaan karyawan mencakup pemberian tugas - tugas baru dengan tanggung jawab yang lebih besar terhadap karyawan atau memberikan keleluasaan dalam merencanakan dan melaksanakan pekerjaannya kepada karyawan (Blanchard, Carlos, \& Randolph, 1995; Stewart, 1998). Ketika diberikan wewenang - wewenang baru dengan tanggung jawab lebih besar, maka karyawan akan melihat bagaimana dukungan yang diberikan perusahaan terhadap proses pelaksanaannya. Apakah misalnya, kurangnya dukungan dalam ketersediaan sumber daya untuk melaksanakan tugas, kemudian tugas tugas diberikan tanpa mempertimbangkan kemampuan karyawan, atau dalam hal penghargaan yang tidak sesuai ketika pekerjaan itu selesai dilakukan, maka hal ini justru akan membuat persepsi karyawan terhadap dukungan organisasi dalam proses pemberdayaan ini semakin lemah.

Apabila persepsi karyawan terhadap dukungan yang diberikan oleh organisasi tidak sesuai dengan harapannya, maka karyawan akan menganggap pemberdayaan yang dilakukan oleh perusahaan hanya satu bentuk eksploitasi terhadap kemampuan yang dimiliki oleh karyawan (Eisenberger et al., 2002). Maka selanjutnya, sesuai dengan teori pertukaran sosial yang dikemukakan oleh Blau (1964), ketika karyawan merasa dukungan yang diberikan perusahaan tidak sesuai dengan harapannya, maka akan menurunkan komitmennya terhadap perusahaan dan pekerjaannya yang ditandai dengan ketidakpedulian terhadap pekerjaan dan 
menunjukkan perilaku - perilaku yang merugikan perusahaan (Levinson, 1965).

Kesimpulan yang sama juga dikemukakan oleh Bhatnagar (2008) serta Chen dan Chen (2008) yang menyimpulkan bahwa beberapa dimensi dari empowement berhubungan negatif dengan komitmen organisasi pada penelitian mereka di India dan taiwan. Penelitian yang dilakukan oleh Allen et al. (2003) memperkuat hasil penelitian ini di mana menurutnya empowerment memiliki hubungan yang tidak langsung terhadap terbentuknya komitmen karyawan, di mana persepsi terhadap dukungan organisasi bertindak sebagai mediator di dalam hubungan tersebut.

\section{KESIMPULAN}

\section{Empowerment}

berpengaruh signifikan dengan persepsi terhadap dukungan organisasi. Hal ini berarti apabila persepsi karyawan terhadap proses empowerment adalah positif maka positif pula persepsinya terhadap dukungan dari organisasi, dan sebaliknya.

2. Persepsi terhadap dukungan organisasi berpengaruh signifikan dengan komitmen organisasi. Jadi, apabila persepsi karyawan terhadap dukungan organisasi adalah positif, maka komitmennya terhadap perusahaan akan semakin tinggi.

\section{Persepsi terhadap dukungan} organisasi bertindak sebagai mediator pengaruh antara empowerment terhadap persepsi dukungan organisasi, di mana mediasi yang terbentuk adalah mediasi sempurna.

\section{SARAN}

\section{Saran Metodologis}

a. Dalam penelitian ini, peneliti hanya menggunakan karyawan - karyawan yang bekerja di kantor pusat sebagai subjek penelitian sehingga belum dapat mewakili seluruh karyawan PT. X di wilayah kerja lainnya. Oleh karena itu, untuk penelitian selanjutnya peneliti dapat menambah subjek penelitian dengan mencakup seluruh wilayah kerja PT. X sehingga hasilnya dapat mencakup seluruh karyawan.

\section{Saran Praktis}

a. Dari hasil penelitian di dapatkan bahwa sebagian besar karyawan mempersepsikan proses empowerment di dalam perusahaan masih pada kategori netral, yang berarti masih ada beberapa perbaikan yang perlu dilakukan oleh perusahaan terhadap proses tersebut. Salah satu caranya adalah perusahaan dapat menyusun SOP pemberdayaan karyawan yang mencakup sifat dan jenis pekerjaan yang dapat diberdayakan, bagaimana menentukan karyawan yang akan diberdayakan, prosesnya, evaluasi dari proses tersebut, sampai kepada penghargaan seperti apa yang diterima oleh karyawan ketika berhasil menyelesaikan tugas yang diberikan. Penyusunan SOP juga dapat menjadi bentuk dukungan perusahaan yang akan menjamin efektivitas pemberdayaan karyawan dan menghindari adanya eksploitasi dari atasan kepada bawahannya.

\section{DAFTAR PUSTAKA}

Akalın, C. (2006). Organization based selfrespect as the organizational support and intervening variable that the employees perceive in the development of affective organizational commitment. (Master 
Thesis). Hacettepe University Institute of Social Sciences, Ankara

Allen, D. G., Shore, L. M., \& Griffeth, R. W. (2003). The role of perceived organizational support and supportive human resource practices in the turnover process. Journal of Management, 29(1), 99-118.

Baird, K. \& Wang, H. (2010). Employee empowerment: extent of adoption and influential factors. Personnel Review, 39(5), 574-599

Baron, R. M., \& Kenny, D. A. (1986). The moderator-mediator variable distinction in social psychological research: Conceptual, strategic, and statistical considerations. Journal of Personality and Social Psychology, 51(6), 1173-1182.

Bhatnagar, J. (2007). Predictors of organizational commitment in India: strategic HR roles, organizational learning capability and psychological empowerment. International Journal of Human Resource Management, 18(10), 1782-811.

Blanchard, K. H., Carlos, J. P., \& Randolph, W. A. (1995). The empowerment barometer and action plan. Es condido, CA: Blanchard Training and Development.

Blau, P. M. (1964). Exchange and power in social life. New York: Wiley.

Boudrias, J., Luc Brunet, A. S., Patrick, P., Alexandre, J.S.M., \& Gerlanda, C. (2010). Empowering employees: The moderating role of perceived organisational climate and justice. Canadian Journal of Behavioural Science, 42(4), 201-211.
Chen, H. F. \& Chen, Y. C. (2008). The impact of work redesign and psychological empowerment on organizational commitment in a changing environment: an example from Taiwan's state-owned enterprises. International Public Management Association for Human Resources, $\quad 37,279-302$.

Dursun, E. (2015). The relation between organizational trust, organizational support, and organizational commitment. Academic Journals, 9(4), 134- 156

Eisenberger, R., Stinglhamber, F., Vandenberghe, C., Sucharski, I.L., \& Rhoades, L. (2002). Perceived supervisor support: Contributions to perceived organizational support and employee retention. Journal of Applied Psychology, 87, 565-573.

Elnaga, A., \& Imran, A. (2014). The impact of employee empowerment and job satisfaction: theorytical study. American Journal of Research Communication, 2(1), 13-26.

Gouldner, A. W. (1960). The norm of reciprocity: A preliminary statement. Amer. Sociol. Rev, 25, 161-178.

Gündüz, Y. (2014). The effect of organizational support on organizational commitment. Anthropologist, 18(3), 1041-1057.

Hales, C. \& Klidas, A. (1998). Empowerment in five-star hotels: choice, voice or rhetoric? International Journal of Contemporary Hospitality Management, 10(3), 88-95. 
Kraimer. J. (2001). Organisasi dan konsep manajemen terpadu. Jakarta:

Penerbit Erlangga.

Kreitner, R \& Kinicki, A. (2004). Organizational behaviour. (6th ed.). United States of America : Irwin McGraw-Hill.

Levinson, H. (1965). Reciprocation: The relationship between man and organization. Administrative Science Quarterly, 9, 370-390.

Loi, R., Ngo, H.Y. \& Foley, S. (2006). Linking employees justice perceptions to intentions to leave: The mediating role of perceived organisational support. Journal of Occupational and Organisational Psychology, 79, 101-120.

Maskat, D. (1993). Manajemen kepolisian: teori dan praktek. Bandung: Sespim POLRI

Mathis, R. L., \& Jackson, J. H. (2001). Manajemen sumber daya manusia (D. Angelica, Pengalih Bhs.). (Edisi Pertama). Jakarta: PT Salemba Empat.

Meyerson, G. (2012). Effect of empowerment on employees performance. Advanced Research in Economic and Management Sciences, 2, 40-46.

Mishra, A. K., \& Spreitzer. G. M. (1998). Explaining how survivors respond to downsizing: The roles of trust, empowerment, justice, and work redesign. Academy of Management Review, 23, 567-588.

Mowday, R.., Porter, L. \& Steers, R. (1982). Employee organization linkages: The psychology of commitment, absenteeism, and turnover. New York: Academic Press
Parameswari, A. A. A., \& Rahyuda, A. G. (2014). Pengaruh pemberdayaan karyawan terhadap persepsi dukungan organisasi dan komitmen organisasi (Studi pada badan lingkungan hidup kabupaten Gianyar). E - Jurnal Manajemen, 3(12), 3781-3800

Randolph, W. A. (1995). Navigating the journey to empowerment.

Organizational Dynamics, 23(4), 19-32.

Rhoades, L., Eisenberger, R., \& Armeli, S. (2001). Affective commitment to the organization: The contribution of perceived organizational support. Journal of Applied Psychology, 86, 825-836

Rhoades, L., \& Eisenberger, R. (2002). Perceived organizational support: A Review of the literature. Journal of Applied Psychology, 87, 698-714.

Salazar, J. P. (2000). The relationship between hospitality employee empowerment, overall job satisfaction, and organizational commitment: a study of race and gender differences. (Disertation). Auburn University, Alabama

Santoso, S. (2000). Buku Latihan SPSS statistik parametrik. Jakarta: PT. Elex Media Komputindo.

Shackleton, V. (1995). Business leadership. London: Routledge.

Stewart, A. M. ( 1998 ). Empowering people (A. M. Hardjana, Pengalih Bhs). Yogyakarta: Kanisius.

Sugiyono. (2010). Metode penelitian kuantitatif, kualitatif, dan $R \& D$. Bandung: Penerbit Alfabeta.

Wayne, S. J., Shore, L. M., \& Liden, R. C. (1997). Perceived organizational 
164

support and leader - member exchange: a social exchange perspective. Academy of Management Journal, $\quad 40, \quad 82-111$. 
